\title{
DACE STRELĒVICA-OŠIN,A
}

University of Latvia, Latvian Language institute

\section{THE LANGUAGE OF CORRECTNESS: SOME TERMS OF LATIN ORIGIN}

\section{Brief summary}

This article reflects on the terminology used in linguistics and sociolinguistics to describe some phenomena related to language correctness and its perception. Accidentally or not (taking into account the fact that in the Ancient Roman society the issues of language correctness were highly important), the major terms used in this context are of Latin origin. Namely, we are speaking of words like purism, prescriptivism, and (in the case of the English language) the term correctness itself. Some historic retrospect is given, considering the time and circumstances when the terms purist / purism and prescriptive / prescriptivist / prescriptivism first appeared in their [socio]linguistic sense. The presence and perception of these terms in the Latvian linguistic community is also briefly discussed.

Keywords: language, correctness, purism, prescriptivism, terminology.

Several years of my research activity have been devoted to one of the probably most controversial sociolinguistic phenomena - the human attempt to deliberately maintain language purity and correctness. Actually, these are two separate phenomena (even though closely interrelated), and they are denoted by the terms purism and prescriptivism. In my earlier work, I have been concentrating on various manifestations of these phenomena in various cultures, also tracing their presence in the antiquity. Especially in the Ancient Roman community, as it is known and shown by various sources and researchers, the correctness of language and observance of norms were held to be particularly important. In this paper, I am looking more closely at the Latin roots of the terms denoting (and related to) this phenomenon - the tendency to guard the language from incorrectness and to keep it in order. Interestingly indeed (and not only in this context, but in various branches of linguistics) - many of the terms pertaining to language system, order and norms are of Latin origin. That includes the 
terminology of parts of speech (noun, verb, adjective, etc.), grammatical cases (nominative, genitive, dative, etc.), various grammatical categories (feminine, masculine, neutral; singular, plural, etc.), and so on. Meanwhile, the terms that describe the creativity and vivacity of language - e.g. those denoting stylistic devices (metaphor, epithet, metonymy, etc.), or semantic variation (polysemy, synonym, antonym, etc.) - are often of Greek origin. In a way, it might be regarded as an example of the presumed antithesis once formulated by Oswald Spengler as 'the Greek soul and the Roman intellect' (griechische Seele und römischer Intellekt) in his Untergang des Abendlandes (1918). However, even though there may be some logic in this comparison of various types of linguistic terminology, to assert this as a general fact would be a poetic exaggeration. After all, such term as grammar, which denotes the very structure of language (and thus also the rules governing this structure), is of Greek origin ( $\gamma \varrho \alpha \mu \mu \alpha$ 'letter';

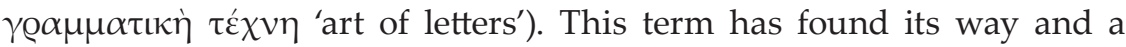
stable place in many languages - as well as its various derivatives with different meanings. Thus, for instance, in Modern Latvian there exist the etymological cognates grāmata, gramatika and glamūrs, all stemming from the same Greek etymon but having arrived via different languages and in different epochs and contexts. However, returning to the issue of language correctness - it is to be noted that the term grammar in English (and its equivalents in other languages) in popular use often refers to anything linked to language usage and particularly to the control of its correctness. As noted by sociolinguist Anne Curzan:

In public discourse, "grammar" is often used to refer to prescriptive approaches to usage, with 'usage' encompassing spelling, pronunciation, punctuation, word meaning, and stylistic choice, in addition to morphology and syntax.

(Curzan 2014, 22)

The well-known meme grammar Nazi, which is used to jokingly denote a person who corrects other people's language errors and misspellings (especially when it happens in internet discussions or other informal settings), also stems from the perception of the term 'grammar' as covering anything that refers to correct language usage. The same perception very much exists in the Latvian linguistic community, as well.

However, the link between grammar and correctness was also present in the Ancient Roman concept of grammaticus ('grammarian'). 
As pointedly formulated by Robert A. Kaster, grammaticus was the gatekeeper "standing where linguistic, geographic, and social distinctions converged" (Kaster 1997, 18). This conclusion is based on and supported by definitions given by ancient authors as well. For instance, Seneca referred to the grammarian as custos sermonis ('the guardian of lan-

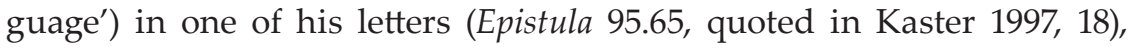
but St. Augustine - as custos historiae ('the guardian of history i.e. tradition') (De musica, 2.1.1, quoted in Adams 2013, 44). Let us also remember Quintilian's famous definition of grammar as recte loquendi scientia ('the art of speaking correctly'), and his analysis of vitia elocutionis ('the vices of speech' i.e. errors) in his impressive work Institutio oratoria. These and other facts all testify to the importance of language correctness and the puristic and prescriptive tendencies in the Latin linguistic community. However, the very terms denoting these tendencies emerged only much later - but with Latin roots nevertheless.

In the case of purism, the term denoting a person practicing it appeared before the denotation of the practice itself. The first attested use of 'purist' was in its French form puriste, in the early $17^{\text {th }}$ century (more on this see in: Peter Burke 1998, Jean-Pierre Seguin 1999, etc.). Namely, that was the first use of this word in reference to a language purist, because actually the French word puriste first appeared with a religious meaning, close to the concept of 'puritan', in 1586 (see Jean-Benoît Nadeau and Julie Barlow 2006, and other sources).

In a way, puriste and purisme are native words in French, since the French adjective pur ('clean; pure') stems from the Latin word purus, i.e., it is inherited in French from its parent language Latin. At the same time, since they are hybrid words consisting of a Romance root and a Greek suffix (the latinised suffixes -ismus, -ista stem from Greek - $\sigma$ $\mu$ ós, $-\iota \sigma \tau \eta \zeta)$, they can also be regarded as the so-called learned borrowings words consciously borrowed from a classical language into a modern one. From France, where the ideas of linguistic purism were cultivated by the Académie française, this term later spread to other languages. In the English language, the word 'purist' (a borrowing from the French puriste) was first used in the 1706 edition of Edward Phillips' dictionary "The New World of Words". The "Oxford English Dictionary" (OED) illustrates this usage with the following quote: "Purist, one that affects to speak or write neatly and properly" (Phillips, quoted in OED XII 
1989, 870; underlining here and henceforth mine, unless otherwise noted). The term 'purism' (from French purisme) was first used in English almost a century later - in what OED simply refers to as '1804 Mitford Inquiry' (and which most probably is William Mitford's work "An inquiry into the principles of harmony in language, and of the mechanism of verse, modern and antient (sic!)") and whereof OED provides this quote: "Before we attempt to exercise on our language the spirit of what the French used to call purism" (Mitford 1804, quoted in OED XII 1989, 870).

It would be too overwhelming a task to trace and describe the history of the term 'purist' in all major languages of Europe. Thus, only a few examples of its usage and interpretation will be given. E.g. the terms der Purist and der Purismus in the German language were certainly well-known by the $18^{\text {th }}$ century, the lifetime of Johann Wolfgang Goethe. More than once, the poet expressed his negative attitude towards the puristic tendencies typical of the German linguistic community at that time - for instance, in one of his aphorisms (published posthumously in Maximen und Reflexionen) he says: "The pedantic purism is an absurd refusal to widen one's mind and spirit" (Goethe 1833, translation from German mine). Likewise, in "Die Xenien" (1797), the collection of ironic distichs by J.W. Goethe and Friedrich Schiller, one of the distichs is as follows:

\section{“152. Der Purist.}

Sinnreich bist du, die Sprache von fremden Wörtern zu säubern, Nun so sage doch, Freund, wie man Pedant uns verdeutscht."1

The author shows his disapproval of purism by poking fun at the fact that der Pedant - a word obviously being regarded as almost synonymous with der Purist at that time - is not a "pure" native German word itself. Interestingly, an English-German dictionary of 1801 translates the English term purism as 'der Purismus, die Sprachreinigkeit' (Nathan Bailey's Dictionary 1801, 663) - thus, the very term that denotes purism has indeed been purified there.

It is not surprising that the contemporary authors, too, when discussing the topic of language purism, have pointed out that the term itself, being of foreign origin, does not conform to the principles of language purity. For instance, the British historian Peter Burke has said about 
William Barnes (a 19 $9^{\text {th }}$-century British poet and philologist, known for his attempts to replace foreign borrowings with native Anglo-Saxon words) that he would call him a purist, were that word not of a Latin origin - therefore, the term 'cleanser' would be appropriate (Burke 1998). Similarly, a Latvian author Gatis Dilāns once offered to replace the term pūrisms by a semi-calque translation tìrisms (Dilāns 2003), derived from Latvian adjective tirs 'pure, clean' in combination with the same Greek-based suffix -isms. Nevertheless - it is fairly logical that purists themselves would not use the term purism (and thus would not worry about its being "impure"), because this term undoubtedly has a negative connotation and thus would not be used by those who support the puristic views and practices.

The negativity encoded in this term can also have various functions. E.g. during the Soviet times in Latvia, the word pürisms was sometimes used when speaking about the language situation during the pre-war period. Under the Soviet regime, academics and other authors were expected (or rather compelled) to be critical of the pre-Soviet epoch. Thus, the Latvian linguist Alise Laua has had to write of "the tendencies of purism (excessive language cleansing) provoked by the bourgeous nationalism" (Laua [1970] 1981, 119; transl. from Latvian mine), not omitting the necessary buzzword bourgeous nationalism. Ironically, the language policy during the Soviet regime was also rather puristic (especially in regard to sub-standard vocabulary), but of course it was not defined as such in those times.

The positively-coloured Latvian terms that denote the upkeeping of language correctness and purity are valodas kopšana 'language cultivation' and valodas kultūra 'language culture' - cf. German Sprachpflege and Sprachkultur. Interestingly, as also pointed out by German sociolinguist Judith Landrø, the term Sprachkultur (which actually stems from the Prague school concept of jazyková kultura) and its equivalents had become particularly popular in East Germany and Soviet Union, while in West Germany the term Sprachpflege was preferred (Landrø 2008, 19). Noteworthy is the mention and interpretation of the concept of purism in Inta Freimane's substantial monography on language culture (1993), published in the first years of independant Latvia. She admits that purism can also have positive features - e.g. "genuine concern about the development of a particular national culture and language" (Freimane 1993, 52; transl. from Latvian mine). 
Still, in Latvian the term 'pürisms', even though well-known to people of philological education or interests, remains quite foreign to the society outside that circle. Meanwhile in English, with its largely Latin- and French-based vocabulary, the terms purism and purist fit in naturally, especially because other words of the same root (pure, purity, purify, Puritan etc.) were adopted already a long time ago.

Prescriptivism, no doubt, is a much more specific term than purism - in any language. As OED informs, the English adjective 'prescriptive' (< Late Latin praescriptious < Latin praescribere, praescripsi, praescriptum) was most probably first used in the linguistic sense in 1933 by Otto Jespersen: "Of greater value (..) than prescriptive grammar is this purely descriptive grammar" (Jespersen 1933; quoted in OED XII 1989, 392). The noun 'prescriptivist' is reported to have been first used by Thomas Pyles in 1952: “(..) why absolute uniformity, the desideratum of the prescriptivist, should be any particular concern of the student of language" (Pyles 1952; quoted in OED XII 1989, 392). The noun 'prescriptivism' appeared soon afterwords, in Archibald Hill's article Prescriptivism and Linguistics in English Teaching: "(..) what is taught in an English class must be some form of (..) prescriptivism" (Hill 1954; quoted in OED XII 1989, 392). Before being used by O. Jespersen in reference to grammar, the adjective prescriptive (meaning "giving directions/instructions") in English was first registered in 1748; verb to prescribe ("to write as a rule/ direction") - in 1535; and noun prescription ("action of prescribing") - in 1542, etc. As OED shows, there have also been such words as prescriber, prescriptible, prescribement, etc. which are lesser-known today. The gradual course from the $16^{\text {th }}$ century prescribe to the $20^{\text {th }}$ prescriptivism shows the derivation process from a morphologically simpler unit into a more and more complex one, and the semantic development from a concrete concept to a more abstract one. However, the sociolinguistic terms prescriptivist and prescriptivism fit in quite well in the English language, because this word family is large and long-established there. In German, as it seems, the corresponding term der Präskriptivismus is relatively less-used.

Nevertheless, prescriptivism in the English-speaking world is controversial not only as a phenomenon, but as a term as well. In the late $20^{\text {th }}$ century, when sociolinguists started to analyze prescriptivism as an object worthy of research (rather than something to be ignored and 
dismissed, as it had been done in Western linguistics for most of that century), they realized that the word 'prescriptivism' had acquired too many negative connotations. Therefore, Deborah Cameron in her famous book of 1995 offered 'verbal hygiene' as a replacement for the term 'prescriptivism'. However, the latter has survived and is still used, most probably because it is recognized by and familiar to most scholars involved in linguistic issues - even though this recognition does not always mean precise understanding and formulation. As Anne Curzan (2014) rightly remarks: "Descriptivism is the "good guy" in the study of language. As a result, prescriptivism has rarely received an extended definition in its own right" (Curzan 2014, 12). Indeed, when looking at various sources, one notices that most definitions of prescriptivism are rather vague, and the superordinate terms included in the definitions are very varied. A phrase that begins as 'Prescriptivism is ...' may then be followed by 'an approach', 'an attempt to ...', 'an activity', 'a practice', 'a set of beliefs', and so forth (and then followed by a description of what this approach, practice, etc. implies).

In Latvian, the term preskriptivisms began to appear in the late 1990s in the works of some linguists. The first monograph devoted to the phenomenon of prescriptivism (Strelēvica-Ošina 2011) appeared in Latvian only in 2011. Still, this term is not yet very widespread; people have sometimes described the word preskriptivisms as difficult to pronounce, some have suggested that it should be replaced by a Latvian term, etc. Even though, from the point of view of logic, this term is neither less nor more complicated than many other terms stemming from the classical languages, it is understandable that a less familiar word may seem harder to accept and use.

There are some more Latin-based terms related to language norms and correctness, worthy to mention. For instance, there is/was the term usus 'usage', an unadapted Latin borrowing used in its original form, which was important in the theories of early $20^{\text {th }}$ century Danish linguists Louis Hjelmslev and the above-mentioned O. Jespersen. Latvian authors have used its Latvianized equivalent ūzuss for some time (e.g. in the already noted I. Freimane's book (1993) and occasionally still nowadays). However, ūzuss in Latvian (sounding very much like ūzas, an archaic word for 'trousers'), in the aspect of euphony is an even less comfortable word than the tongue-twister-like preskriptivisms. Obviously, no 
wonder that nowadays in Latvian linguistic literature the word lietojums 'usage' highly surpasses ūzuss in frequency and popularity.

And, last but not least, the word correctness itself deserves to be noted, because in English it is a word of Latin origin. As OED informs, the English verb to correct (< Latin corrigere, correxi, correctum) was first attested in 1340, meaning "to amend, set right (an error)" (OED III 1989, 961). Later in the same century, in 1374 it was first used in a languagerelated context: "to correct a text, to proof-read". The adjective correct (< Latin correctus) appeared in 1676 (OED III 1989, 961), but the noun correction (< Anglo-French correccioun < Latin correctio) has been around already since 1340 (OED III 1989, 962).

Meanwhile, the Latvian words pareizs ('correct') and pareiziba ('correctness') are among those obscure borrowings that, no doubt, are perceived as native words by most speakers. The etymological dictionary by Konstantins Karulis describes them as being derived from the phrase pa reizei 'at times', where reize 'time/turn [of doing something]' stems from German Reise, reisen 'travel; to travel' (Karulis 1992, 21). The Latin word correctus, though, has also given rise to some Latvian words korekts (borrowed via German korrekt) meaning 'decent', and korektors (< German der Korrektor) - 'proof-reader'.

Certainly, if time and space would allow, one might expand on this topic even more. Latin roots are at the basis of such terms as descriptivism (the opposite that actually gave rise to the concept of prescriptivism in linguistic thought), culture (cf. the collocation 'language culture'), and also language and linguistics, for that matter. The Latin impact on modern languages is as immense as the tradition of correctess is in human history.

\section{REFERENCES}

1 "152. The Purist. / So smart you are, cleaning the language from foreign words. / Do tell me, my friend, what is the German for 'Pedant'? (Translated by Dace Strelēvica-Ošina)

\section{SOURCES}

1. Augustinus Hipponensis. De musica, 2.1.1. Quoted in: J. N. Adams. Social Variation and the Latin Language. Cambridge : Cambridge University Press, 2013, 44.

2. Dilāns, Gatis. Valodas standartizācijas sekas. Diena, 4. oktobris, 2003.

3. Goethe, Johann Wolfgang. Maximen und Reflexionen. Stuttgart, Tübingen : Cotta, 1833.

4. Goethe, Johann Wolfgang; Schiller, Friedrich. Xenien. Musen-almanach für das Jahr 1797. 
5. Mitford, William. An inquiry into the principles of harmony in language, and of the mechanism of verse, modern and antient. London : T. Cadell \& W. Davies, 1804.

6. Nathan Bailey's Dictionary, English-German and German-English: Englisch-deutsches und Deutsch-englisches Wörterbuch. Leipzig und Jena : F. Frommann, 1801.

7. Phillips, Edward. The New World of Words. London, 1706.

8. Quintilianus, Marcus Fabius. Institutio Oratoria, Liber I: 4, 2. Available: http://www. thelatinlibrary.com/quintilian/quintilian.institutio.shtml [viewed 01.01.2002].

9. Seneca, Lucius Annaeus. Epistula 95.65. Quoted in: R. A. Kaster, 1997, 17.

10. Spengler, Oswald. Untergang des Abendlandes. Erster Band. Wien, Leipzig: Braumüller, 1918.

\section{LITERATURE}

1. Burke, Peter. Langage de la pureté et pureté du langage. / Terrain, Numéro 31 (septembre 1998), mis en ligne le 14 mai 2007. Available: http://terrain.revues.org /document3142. html [viewed 10.04.2017].

2. Cameron, Deborah. Verbal Hygiene, London : Routledge, 1995.

3. Curzan, Anne. Fixing English. Prescriptivism and Language History, Cambridge University Press, 2014.

4. Freimane, Inta. Valodas kultūra teorētiskā skatījumā. Rīga : Zvaigzne, 1993.

5. Hill, Archibald. Prescriptivism and Linguistics in Language Teaching. / College English, Vol. 15, 1954.

6. Jespersen, Otto. Essentials of English Grammar, London: George Allen \& Unwin, 1933.

7. Karulis, Konstantīns. Latviešu etimoloǵijas vārdnīca II. Rīga : Avots, 1992.

8. Kaster, Robert A. Guardians of Language: the Grammarian and Society in Late Antiquity. University of California Press, 1997.

9. Landrø, Judith. Purismus als Strategie europäischer Sprachpolitik, Hamburg : Verlag Dr. Kovač, 2008.

10. Laua, Alise. Latviešu leksikolog̣ija. Rīga : Zvaigzne, [1970] 1981.

11. Nadeau, Jean-Benoît; Barlow, Julie. The Story of French. St. Martin's Press, 2006.

12. Oxford English Dictionary. Volume III. Oxford : Clarendon Press, 1989.

13. Oxford English Dictionary. Volume XII. Oxford : Clarendon Press, 1989.

14. Pyles, Thomas. Words and ways of American English. Random House, 1952.

15. Seguin, Jean-Pierre. La langue française aux XVIIe et XVIII siecles. Chaurend, J. (ed.), Nouvelle histoire de la langue française, Paris : Éditions du Seuil, 1999.

16. Strelēvica-Ošiña, Dace. Kāpēe mēs gribam, lai valoda ir pareiza? Ieskats preskriptīvisma vēsturē, teorijā un praksēe. Rīga : LU Latviešu valodas institūts, 2011.

\section{PAREIZĪBAS VALODA: DAŽI LATĪṆU IZCELSMES TERMINI}

\section{KOPSAVILKUMS}

Rakstā aplūkota terminologija, kuru sociolingvistikā lieto, lai apzīmētu dažas ar valodas pareizību un tās uztveri saistītas parādības. Visdrīzāk, tā nav nejaušība, ka galvenie šai kontekstā lietotie termini ir latīnu izcelsmes - ņemot vērā to, ka Senajā Romā valodas pareizības 
jautājumiem tika piešķirta liela nozīme. (Interesanti, ka arī citās valodniecības nozarēs vairums starptautisko terminu, kas attiecas uz valodas struktūru un "kārtību", ir latīṇu izcelsmes - vārdšḳiru nosaukumi substantìvs, verbs u. c., locijumu nosaukumi nominatìvs, ǵenitìvs utt. Savukārt tie termini, kas apraksta valodas dažādību un radošo potenciālu, bieži ir grieķu izcelsmes - stilistisko līdzekḷu nosaukumi metafora, epitets u. c., kā arī jēdziens semantika un tā atvasinājumi utt.)

Šai rakstā runa galvenokārt ir par terminiem pūrisms un preskriptīvisms, pieminot arī angḷu valodas vārdu correctness ('pareizība') un vēl dažus terminus. Aplūkota arī šo vārdu vēsture, atskatoties uz laikmetiem un apstākḷiem, kad jēdzieni pūrists/pūrisms un preskriptīos/ preskriptīvists/preskriptīvisms parādījās vai arī ieguva savu valodniecisko nozīmi. Skarta arī šo jēdzienu un terminu izpratne latviešu valodas vidē. 